\title{
Primary and Hospital Healthcare in Poland - Organization, Availability and Space
}

\author{
Paweł Kretowicz and Tomasz Chaberko \\ Jagiellonian University \\ Poland
}

\section{Introduction}

Spatial distribution and location of healthcare facilities have been long acknowledged as main interests of Polish medical geography, although most research done dates back to the late 1980s and early 1990s (Mazurkiewicz, 1994; Michalski, 1999). These include e.g. some renowned studies of health services in Warsaw (Grochowski, 1988; Malczewski, 1989). Unfortunately, healthcare accessibility and availability have not been widely explored by geographers in the 2000s; thus marginalized in spatial sciences, has been detained by other disciplines such as public health (see Chawla et. al, 2004).

In 1952 geography of health was officially recognized and incorporated into geographical sciences by Medical Geography Committee operating within the structures of International Geographical Union. At the time, geography of health endeavored to investigate geographical factors of causes and consequences related to changes in population health status and morbidity. Presently, this subdiscipline consists of two distinctive strands: the spatial distribution of disease and death, and the geographical complexities surrounding the provision, access to and inequality of health care (Kearns \& Gesler, 2002; Parr, 2003). Hence, most researchers clearly distinguish geography of healthcare as a domain that focuses on spatial accessibility of health services through the lenses of their distribution, demand, supply, utilization and planning (Mayer, 1982; Moon et. al., 1998). Moreover, geography of health care has evolved to investigate how medical resources meet population needs in space (Rosenberg, 1998; Kearns \& Moon, 2002). Irrespective of such collaborative approaches some spatiallyaware researchers frequently explore spatial and non-spatial factors underlying healthcare accessibility (Haynes, 2003; Wang \& Luo 2005; Unal et. al, 2007).

The most important regulation of Polish healthcare system guarantees equal access for everyone, which is directly declared in the Polish Constitution, Article 68, Paragraph 2: „Equal access to health care services, financed from public funds, shall be ensured by public authorities to citizens, irrespective of their material situation. The conditions for, and scope of, the provision of services shall be established by statute". As suggested here, equal access refers to free utilization of health services. Although provided and financed by the state, health services should be congruent with other dimensions of accessibility. These are: affordability, accommodation, acceptability, availability and spatial accessibility (Penchansky \& Thomas, 1981). First three dimensions can be viewed as non-spatial, however planning and fund distribution on healthcare in particular regions and counties should be based on potential 
and actual/expected population needs (Guagliardo, 2004). The notions of availability and accessibility describe the relationship between location of healthcare facilities and patient residence. Availability reflects an assessment of how the volume and type of existing services (and resources) reflect the clients (patients) volume and types of needs (Joseph \& Phillips, 1984). Spatial accessibility refers to distance, travel time, cost and modes of transportation.

The most important barrier to egalitarian conditions of healthcare utilization includes much higher demand of medical services as compared to the supply. This demand increases along with economic growth and development of new technologies. The existing medical resources (especially in secondary - specialized care and tertiary - hospital care) can no longer meet the needs of all patients simultaneously, nor do the financial resources can be distributed across all in need. As a consequence, long lines to the specialist offices discourage the sick and make them shift from public to non-public healthcare facilities. Worse still, heath services offered in non-public facilities are not always refunded by the National Health Fund (Narodowy Fundusz Zdrowia - NFZ - the institution responsible for redistribution of insurance contributions); thus patients have to pay for services. Furthermore, annual budgetary limits to health services also constrain access to healthcare and contribute to long wait times. These restrictions result from new technologies in medicine and pharmacy, which provide more efficient, but expensive medical equipment, treatments and medicines. In 2009 only $5 \%$ of patients generated no fewer than $60 \%$ of the total expenditures on services guaranteed by the NFZ (Ruszkowski, 2010).

Commercialization in Polish healthcare system has progressed dynamically since the early 1990s. Presently, about $75 \%$ of general practitioner offices and $82 \%$ of specialist offices in Poland operate as non-public facilities. In case of hospitals this proportion in 2010 amounts to $35 \%$ with a total number of hospital beds in non-public facilities reaching 32.8 thousands (16\% of all hospital beds in Poland). This indicates that the majority of commercialized hospitals comprise relatively small facilities whereas the largest ones remain either state or province-owned.

\section{Data sources and setting}

According to Kaczmarek (2007) the availability of medical services depends on the volume and structure of current resources (e.g. number of medical doctors, nurses, hospital beds, medical equipment). Unfortunately, under the socialist rule before 1989 access to data concerning material and personal resources in healthcare was very limited. Neither existing registers nor Central Statistical Office was capturing data for all of the medical specialties. Besides, official figures were often aggregated and presented as simple classifications (Dziubińska-Michalewicz, 1994). Presently, Central Statistical Office (Local Databank, www.stat.gov.pl) provides scarce information concerning healthcare facilities (total number), although most is available on a municipal level. This data is divided by the ownership (public and non-public), type of care (primary and hospital) and utilization (crude number of consultations with physicians). County-level data includes the number of public and non-public hospital beds and the number of hospitalized patients (until 2003). In order to assess the distribution, organization, ownership and medical staff in healthcare facilities across the country the best databases offer the Register of Health Care Units (Rejestr Zakładów Opieki Zdrowotnej, www.rejestrzoz.gov.pl) and Central Register of 
Health Professionals (Centralny Rejestr Lekarzy, www.nil.org.pl). These sources are extremely useful in geographical analyses of such subjects as:

a. location and organization of healthcare facilities

b. location of new facilities, changes of ownership (since 2004)

c. spatial accessibility and availability of health professionals by specialty

d. number and structure of hospital beds with respect to potential health needs

Center of Health Information Systems operating within the Ministry of Health is the main body responsible for data capture and storage. Annual Survey Programs of Official Statistics include public health data, which obligates every healthcare institution to send the required information to the Center monthly or annually. The records collected facilitate accurate analyses of medical resources and their utilization (data available on a municipal level). For example, MZ-88 and MZ-89 forms are used to collect data about medical staff employed in each health care unit in the whole country. Similarly, forms MZ-11 to MZ-15 include the data about number of patients and consultations with physicians by date, patients' age and sex, type of ailment etc. Analogous information about hospital care can be derived from MZ-11Szp forms provided by every facility in the country (by both facility location and patient residence). Unfortunately, not all hospitals follow this regulation what would result in strong underestimations (no data for one hospital in an area) if any geographical analysis was conducted. All of the data sheets are also sent to Centers of Public Health located in 16 provincial seats. Until recently, these institutions operated as separate entities, but they have now been incorporated into Health Departments of Province Offices. Administrative division of Poland authors wish to refer to in this study is presented below (Figure 1). Poland is divided into 16 provinces (49 until 1999), 314 land and 65 urban counties, 2478 self-governed municipalities.

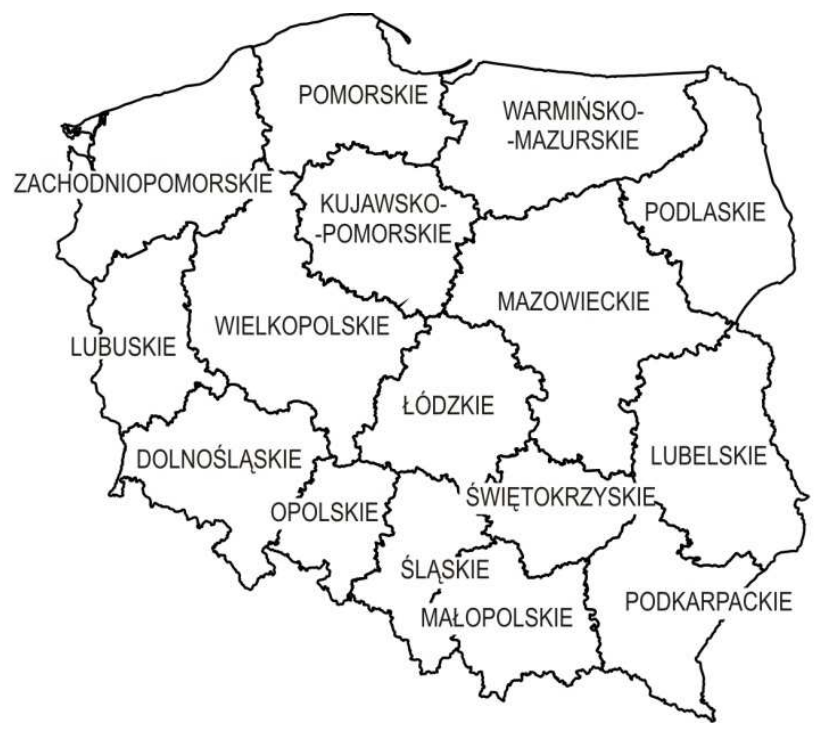

Source: authors' own work

Fig. 1. Administrative division of Poland since 1999. 
This study employs the data extracted from both Register of Health Care Units and Central Statistical Office. According to The Act of 30th September 1991 on Health Care Units (Ustawa z dnia 30 września 1991 o zakladach opieki zdrowotnej; Dz.U. 1991, Nr 220, Poz. 1600.) register entry is tantamount to official permission to run a medical office or health center (fines are levied upon those unregistered). Register of Health Care Units includes detailed information about facility address, location of its branches, legal foundations, organizational structure, type of medical specialty, number of beds in each ward (for hospitals and other inpatient clinics). Unfortunately, some information found in the Register turns out to be unreliable as not all specialist offices are included into the computer database (regardless of declared trustworthiness by the Center of Health Information Systems). For this reason, authors decide to take into consideration only primary and hospital healthcare. In spite of clear attempts to enhance data availability, a lack of necessary information provided by Polish statistical institutions is considered as a major limitation for health-related research and medical geography in particular. The main indicator of primary healthcare availability utilized this study includes practitioner's office to population ratio. In case of hospital care this measure comprises the number of hospital beds to population ratio.

\section{Organization of healthcare system in Poland after World War II}

Contemporary spatial organization of healthcare system in Poland has been shaped by historical determinants, healthcare model employed by the politicians as well as recent socio-economic processes. Under socialist rule, as in many other sectors of the national economy, management and planning in healthcare fell under central authorities. The Act of $28^{\text {th }}$ October 1948 on Collective Health Care Centers and Planned Economy in Healthcare (Ustawa $\mathrm{z}$ dnia 28 października 1948 r. o zakładach społecznych stużby zdrowia i planowej gospodarce w stużbie zdrowia, Dz.U. 1948 Nr 55, Poz. 434.) virtually barred local governments and territorial health care centers from making consecutive decisions in healthcare organization and planning. Every resolution must have been first discussed and then approved by the district departments of national administration. Former healthcare system was organized in conjunction with the administrative division of the country. The provincial hospitals (socalled integrated provincial hospitals - Wojewódzki Szpital Zespolony) were most privileged as they offered the widest variety and highest quality of medical services. As a result, inequalities in spatial distribution of tertiary care increased significantly and favored these provinces with the largest district/regional facilities. Moreover, this gap widened after locations of some institutions in accordance with the political and military will of the Warsaw Pact (Ruszkowski 2008). Such locations were justified ideologically as communistic authorities were determined to arrange sufficient hospital infrastructure for the army in case of war (anticipated World War III). Hence, oversized and strategically-located institutions were being constructed across the entire country, but chiefly in the west of Poland. Consequently, large hospital facilities usually exceeded the needs of local population. A good example of such location could be Stanislaw Staszic's county hospital in Piła (Wielkopolskie Province), of which construction began in 1977 (Photo. 1.)

The number of beds in Stanislaw Staszic's Hospital in Piła peaked in 1992 when comprised as many as 726 beds. This number greatly exceeded local demand and was gradually reduced down to 601 beds in 2010; thus maladjustment of hospital size to the population needs was evident. The same problem concerned the spatial distribution of expenditures on healthcare financed both by the national (institutions of a nationwide range) and the 
provincial budgets (institutions of a regional range). These expenditures were allocated without any regard to spatial distribution of population demand and healthcare utilization. All in all, fund distribution was organized by extrapolation of expenditures incurred in the previous year, providing their maximization with no rights to transfer any expenses for the next year (Curtis \& Malczewski, 1990). Such management was ineffective, inadequate to the current social expectations and put numerous health care units in financial hardship. After the political transformation of 1989, this extensive policy led to shortages of personnel, medical equipment, medicines and favored corruption (Millard 1995).
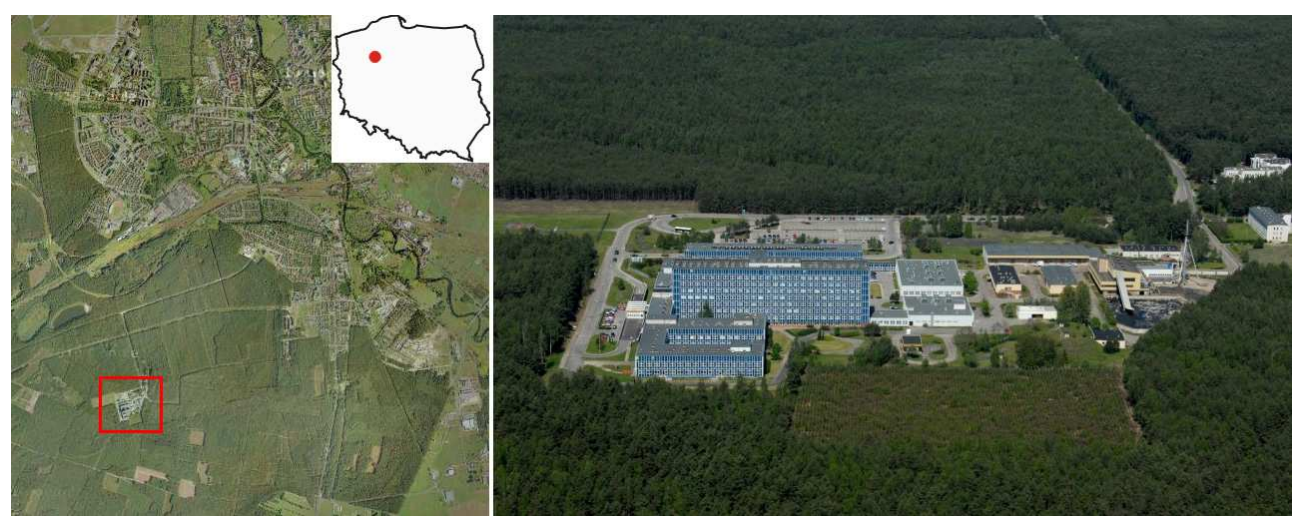

Source: googlemaps.com

Photo 1. Stanislaw Staszic's county hospital in Piła.

The aforementioned system of healthcare managed and financed by the state budget and based on the lack of private health care institutions is called the Semashko model. This model, criticized for the extensive allocation of funds, dominated Poland and other socialist countries in the second half of the $20^{\text {th }}$ century. Healthcare institutions were utilized only by patients who resided in the preventive-therapeutic districts (embracing from 30000 to 150000 inhabitants). Nonetheless, the basic units were called micro-district and embraced from 3000 to 6000 inhabitants. These units had to possess at least one physician in service and cover at least one village or district (borough) (Kaser, 1976). Moreover, health services for certain social groups were organized by completely different public bodies e.g. enterprise health services, railroad health services, Ministry of the Interior Affairs and Ministry of Defense health services (Grochowski, 1988). In 1972, the integrated health care management units - ZOZ (Zespó1 Opieki Zdrowotnej) were established. These entities were responsible for management of hospitals, outpatient clinics, specialist and primary health care as well as some social services. In 1991 health care units replaced integrated health care managements units, but retained the same acronym (ZOZ - Zakład Opieki Zdrowotnej). The Semashko model operated until 1999, when, in the aftermath of reforms in the Polish healthcare, insurance contributions were introduced. By this means, a transition from budgetary to insurance model put healthcare system in Poland on different tracks leading to the Bismarck model (social insurance model). This model introduces mandatory insurances, free choice of service and insurance provider as well as contract-based organization of healthcare system. New model alters spatial patterns of 
healthcare utilization by the patients, who are now allowed to choose health professional and health care institution wherever they wish including locations outside their area of residence. Irrespectively, the system present in Poland is now criticized as the individual contributions remain involuntary, do not depend on individual decisions and the insured have no influence on the quality of service received (Siwińska et. al., 2008).

Presently, changes in Polish healthcare system to some extent follow principals of the Bismarck's model as gradual decentralization of management and financing have been implemented since the early 1990s. From economic and administrative viewpoints this decentralization is reflected by the liberalization of healthcare market, which results in gradual replacements of state health care units by municipal and non-public entities. Local governments (provinces, counties and municipalities) are now allowed to found and manage health care units what is permitted by the Act of 30th September 1991 on Health Care Units. Four forms of health care units are mentioned in this act with respect to their ownership and financial system: independent public health care centers (SPZOZ), budget entity, self-governmental budgetary establishment, and non-public health care unit (NZOZ). Decentralization of financial system and transformation of health care units into independent public health care centers began in 1998 and 1999 after sickness funds were established. This decentralization was reversed in 2003 as National Health Fund was founded, something that led to concentration of financial resources on a national level. The return to central healthcare financier and insurer was fiercely criticized by the politicians and scientific community; thus regional branches of NFZ were established, each responsible for healthcare financing and insurances in one province (but still operating under the Ministry of Health). Consequently, a lack of state-independent insurer and provider of healthcare limits patients' choice, which plainly contradicts the Bismarck's model principals. Contrarily to the healthcare financing and insuring, the responsibilities of management and planning in healthcare were imposed on local governments. Unfortunately, local communities were not able to cover increasing expenses and debts which health care units amassed over the years. These debts resulted from operation in accordance with constitutional principle of equal and free access to health services as well as life saving obligations. Moreover, the financial burdens are excavating prompted by the inability to declare bankruptcy by these health care units which are crucial for local population in order to retain overall health security intact.

\section{Spatial inequalities in the availability of primary and hospital care}

Legal and administrative characteristics concerning the organization of Polish healthcare system have a direct impact on spatial issues of the essence for researchers in medical geography. From an economic perspective, geographical sciences may lie beneath the premises for allocation of funds in particular regions (in accordance with spatially diverse needs) as well as the distribution of decisive and executive competences in health policy (spatial scale problem - consistency between administrative level and responsibility for health policy goals). From a social perspective, a key issue is to increase accessibility to and availability of medical services for all citizens, particularly the poorer friction of population who reside in peripheral areas.

Both spatial accessibility and availability of healthcare was radically improved by the enforcement of legal acts that gave non-public entities rights to run healthcare practices as 
well as make contracts with the National Health Fund. These novelties triggered a continuous increase in the number of health care units and health care centers across the country since 1991, but most intense spread was observed at the beginning of the $21^{\text {th }}$ century. The data currently available allow for investigating these phenomena in a spatial dimension since 2004 (when a computer database - Register of Health Care Units was created). The number of health care units in 2004, 2007 and 2010 per 10 thousand inhabitants is presented in the Figure 2 irrespective of medical specialty and organizational forms. Higher number of health care units contributes to better availability and diversity of medical services. The changes in the number of health care units are inarguably connected with an increase of non-public entities. Because the range of influence for certain units often exceeds the municipal or regional borders (patients choose health professionals located nearby their places of residence) an average measure was calculated. This measure combines each municipality and all adjacent to them according to queen contiguity spatial weights frequently used in spatial statistics.

Most health care centers are located in the largest metropolitan areas both in cities and their vicinity as the suburban inhabitants often utilize health services provided by the institutions located in the inner city. More favorable healthcare availability in metropolitan areas results from large demographic potential, extensive financial resources, and excellent access to specialized medical services, the latter caused by high-rank education provided by medical universities that educate most qualified personnel. Thus, health professionals who obtained rare specializations usually practice in the largest cities. Furthermore, hospital wards with a catchment area encompassing several provinces (e.g. due to the uncommon specialization and rare disease treatment) are located in the largest cities too. Nevertheless, certain areas such as medium-sized towns, especially former province capitals (between 1975 and 1999 Poland was divided into 49 provinces; this period gave an economic boost to provincial capitals), are distinguished by a high-level and numerous medical services. The infrastructure inherited from the period of the People's Republic of Poland contributed to the concentration of health care units in these towns presently. Regional approach demonstrates Śląskie, Łódzkie, Zachodniopomorskie and Podlaskie Provinces as those of the best healthcare availability. Fast pace of changes can be observed in Zachodniopomorskie and Podlaskie Provinces whereas fewer health care units per 10 thousands inhabitants can be found in Kujawsko-Pomorskie, Pomorskie, and WarmińskoMazurskie Provinces.

\subsection{Primary heathcare}

General practitioner is considered as a key element of primary healthcare in Poland. Individual GP practices were established quite recently - in 1991. These doctors are supposed to perform gatekeeper's role that is to provide entrance to the whole healthcare system as a first institution patients refer to. As follows, this role assumes that initial patient-doctor contact begins at general practitioner office (in Poland, these physicians are called family doctors). Theoretically, family doctors ought to possess enough knowledge and experience to cure (or at least assist) the majority of diseases; however they are granted a wide range of administrative competences. Aside from prescriptions, they can issue referrals to other specialists or hospitals and for numerous medical examinations. 


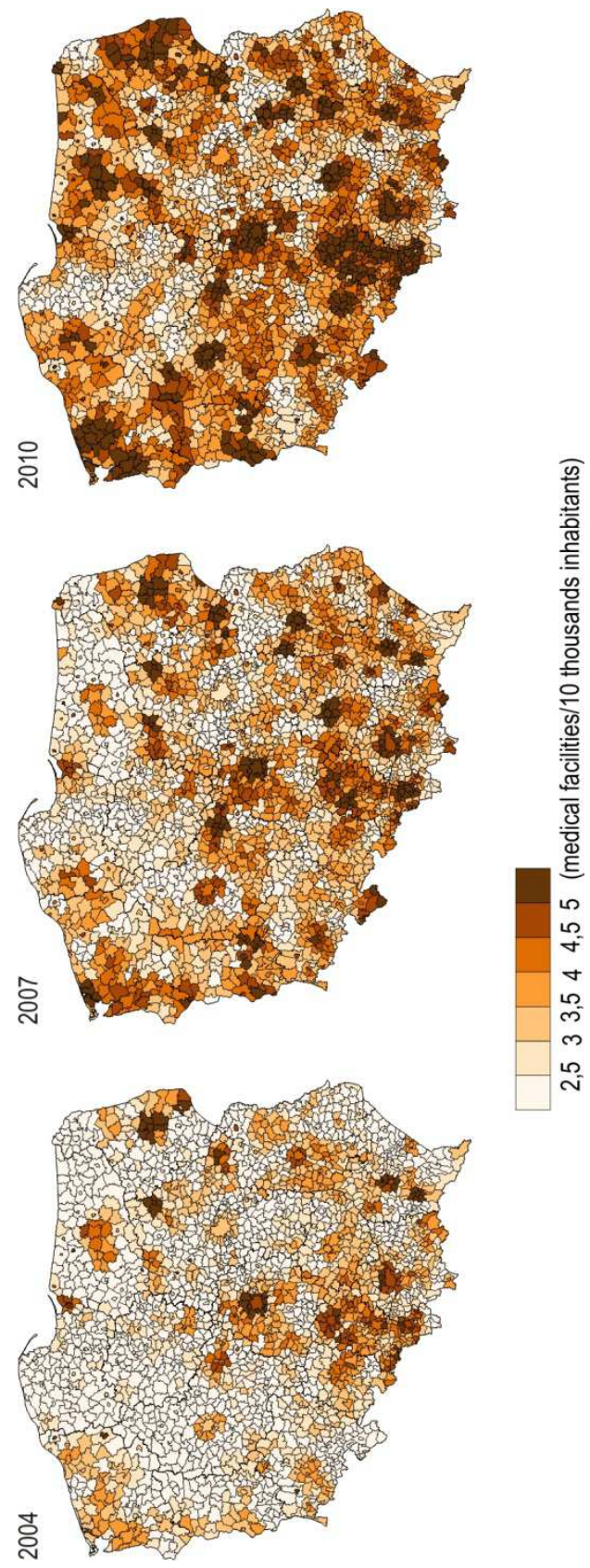

Source: Authors' own work based on Central Statistical Office (www.stat.gov.pl).

Fig. 2. The number of medical facilities per 10 thousands inhabitants in Poland in 2004, 2007 and 2010. 
By this means, their medical functions are limited to distribution of prescriptions (most common and easy-to-cure diseases) or a set of referrals when the case is difficult to diagnose. Moreover, appointments aimed at receiving sick leaves are also very common. Therefore, the contemporary general practitioner office can be dubbed as a generator of referrals/hospitalizations and in this way whole sets of these documents can free family doctors from the responsibility to assist in more difficult and atypical cases. The original idea of family doctor assumes long-term and permanent contact between patients and health professional. The family doctor should be acquainted with patients' medical record and earn his trust through the years. However, frequent rotation of health professionals working in health care centers (mainly these located in cities) abides these goals from being obtainable. In sparsely populated rural areas, health services are usually provided by one general practitioner and a nurse. Moreover, in certain localities only branches of public health care centers are located and services are provided only during a few hours per day.

The foundation of healthcare model based on family doctor in Poland makes treatment more accessible and receivable everywhere, though the free-of-charge care can be obtained in both public and non-public health care unit, provided that the latter made a contract with the National Health Fund. The free choice of family doctor does not change the fact that the majority of patients are registered at general practitioner offices located in the vicinity of their places of residence. This solution is convenient for patients, especially when the change of residence in Poland does not require obligatory registration. Nevertheless, more changes of family doctor than twice a year requires from patient 80 PLN fee, unless this change is caused by a permanent migration to another place of residence, involuntary obligation, or results from other circumstantial conditions beyond patient's control. Patients who wish to change their primary care provider have to declare this will on a proper form. According to the National Health Fund a maximum number of patients registered to one general practitioner should not exceed 2750 (in other words: there should be at least 3.64 family doctors per 10 thousand inhabitants). However, the number of family doctors in Poland amounted to 10206 in 2010, that is 2.67 family doctors per 10 thousand inhabitants (The Polish Chamber of Physicians and Dentists, www.nil.org.pl). This implies that there is rather a shortfall than excess of general practitioners in the country.

The distribution of primary health care units in Poland shows significant spatial diversity among provinces and counties (Figure 3). As for geographical factors of healthcare in different regions, this pattern does not directly refer to the level of socio-economic development, population distribution or historical background. Conversely, a noticeable diversity within certain regions can be observed. Among five provinces with the highest number of health care institutions per 10 thousand inhabitants there are regions of completely different background and socio-economic characteristics. Some diverse as far as primary healthcare availability is concerned counties are adjacent to each other. For example, they include counties located to the west of Poland (territories that used to be a part of Germany before World War II) in Zachodniopomorskie Province as well as less developed regions located to the east (so-called Eastern Wall) represented by Lubelskie Province. Similar diversity can be observed among provinces with the lowest availability of GP offices, e.g. Wielkopolskie and Podlaskie. Whereas the former can be considered as an area of economic prosperity, the latter is rather underdeveloped and experiences 
depopulation processes. Such diversity results from different models of healthcare organization and strategies implemented by local governments, but also spatial inequalities inherited after the Communistic times. In the areas of worse availability of primary care, family practices are probably larger as measured by the number of physicians in service. For this reason, significant differences can be observed between cities with county status (the largest towns and cities) and land counties. The majority of land counties are characterized by favorable accessibility of GP offices, what stems from higher population density and concentration medical facilities as a part of larger health care centers. As for land counties more GP offices per 10 thousand inhabitants are present in those with the lowest population number and density. Despite theoretically lower demand for medical services in these areas the network of GP offices is left uninterrupted what minimizes the distance between patient residence and family doctor.

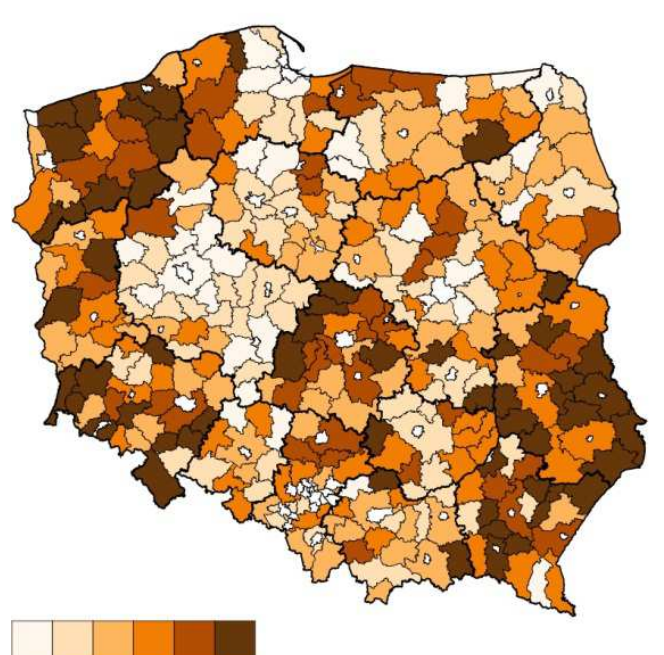

$22,533,54$ [GP offices per 10 thousend inhabitants]

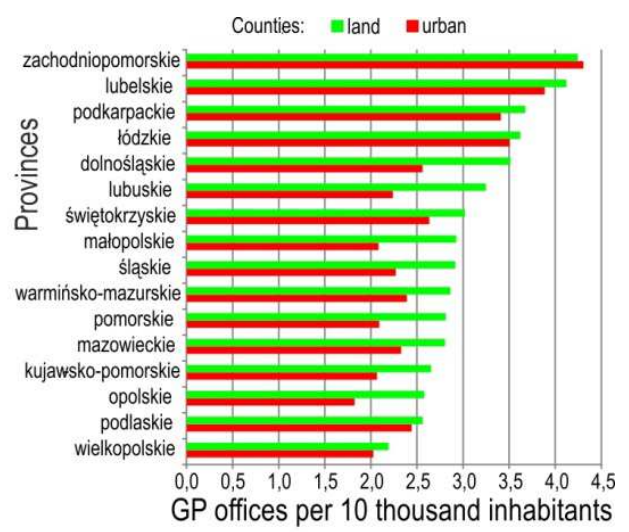

\begin{tabular}{lr} 
POLAND & 3,01 \\
\hline urban counties & 2,57 \\
\hline provincial seats (18) & 2,57 \\
cities above 200 thous. citizens (17) & 2,47 \\
cities below 200 thous. citizens (48) & 2,61 \\
land counties & 3,10 \\
population I quantile & 3,16 \\
population V quantile & 2,74 \\
population density I quantile (63) & 3,44 \\
population density V quantile (62) & 2,82
\end{tabular}

Source: Authors' own work based on Register of Health Care Units (www.rejestrzoz.gov.pl) and Central Statistical Office data (www.stat.gov.pl).

Fig. 3. The number of general practitioner offices per 10 thousand inhabitants in Polish counties and provinces in 2010.

Analyses of primary healthcare on a regional level hide local disparities in health care accessibility reflected by the distribution of population. In order to detect conditions that underlie the availability of primary healthcare four types of areas (counties) in the whole country are singled out. The prerequisite for this selection is a simple spatial typology created according to the number of GP offices per 10 thousand inhabitants and population density (Figure 4). 


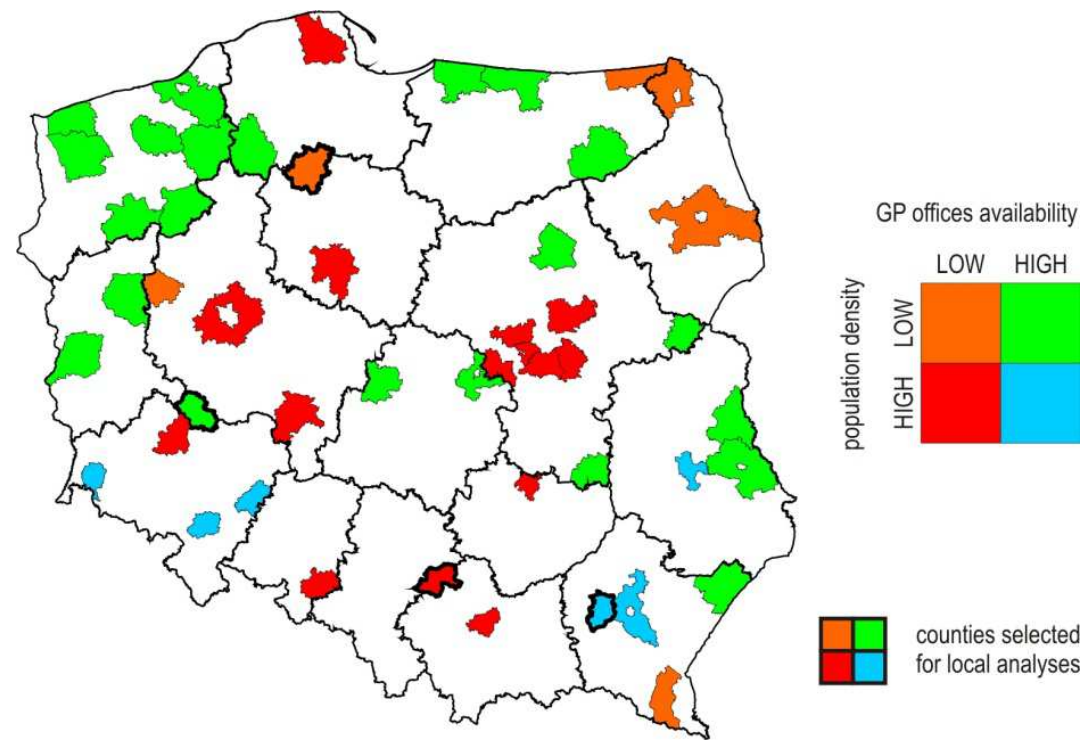

Source: Authors' own work based on Register of Health Care Units (www.rejestrzoz.gov.pl) and Central Statistical Office data (www.stat.gov.pl).

Fig. 4. The rural counties in I (low) and V (high) quintile in general practitioner availability as measured by offices per 10 thousand inhabitants or I (low) and V (high) quintile in population density in 2010 (encircled counties were selected for further local analyses).

The selected areas include:

a. Tucholski County (Kujawsko-Pomorskie Province - orange color) placed in the I quintile in GP offices availability and population density

b. Górowski County (Dolnośląskie Province - green color) placed in the V quintile in GP offices availability and I quintile of population density

c. Olkuski County (Małopolskie province - red color)placed in I quintile of GP offices availability and $\mathrm{V}$ quintile of population density

d. Ropczycko-Sędziszowski County (Podkarpackie Province - blue color) placed in V quintile of GP offices availability and V quintile of population density (Figure 5).

The example of Tucholski County shows that spatial accessibility to family doctors is constrained only in sparsely populated areas of the low GP offices availability. Within Tucholski County there are numerous small villages located further than $10 \mathrm{~km}$ from the nearest GP office, although most are located within the range of $3 \mathrm{~km}$. Such areas are rather rare in Poland and can be found only in the northern part of the country and in some municipalities located in the Carpathians. Among the counties with high population density spatial accessibility is comparable for both the areas of low and high GP offices availability. Nonetheless, the high concentration of GP offices in towns elevates the indicator for the whole county (Ropczycko-Sędziszowski County). The areas characterized by high density of population and considerable number of GP offices are located only in southern Poland. 


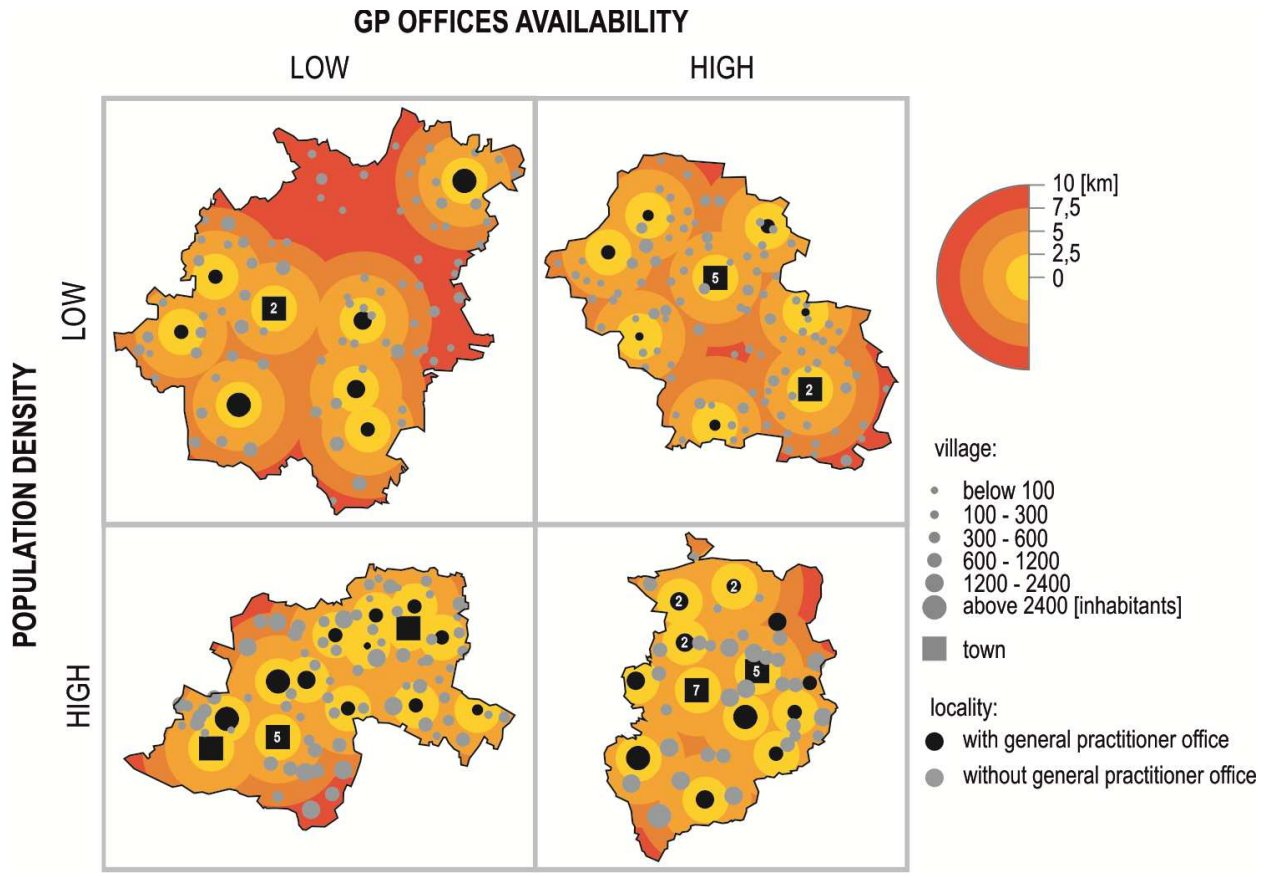

Source: Authors' own work.

Fig. 5. Primary healthcare in four counties of different population density and GP offices availability in 2010.

On the other hand, many sparsely populated counties have a high GP offices availability, what is particularly prominent in Zachodniopomorskie Province. The example of Górowski County demonstrates that, unless there are villages without family doctor offices in operation, the majority of such villages are located within $5 \mathrm{~km}$ distance from the nearest GP office. The opposite situation exists in Olkuski County, where larger villages are located relatively far from GP offices and some concentration of health care institutions is observed only in towns and adjoining villages. Interestingly, within the counties of low availability of GP offices and high population density fall some suburban areas of the biggest cities in Poland such as: Poznań, Warszawa, Gdańsk and Kraków. This proves that inhabitants of metropolitan areas utilize the healthcare services in the central city, what decreases the demand for GP offices in suburban areas.

\subsection{Hospital healthcare}

Inappropriate spatial and organizational structure of Independent Public Health Care Centers (SPZOZ) is believed to underpin the inequalities in Polish inpatient healthcare (Ruszkowski, 2008). Undoubtedly, higher actual net needs (in this case the number of hospitalized patients) concern large urban centers, what directly results from their demographic potential. However, healthcare needs are considered to be the best satisfied 
not in urban centers with a high concentration of healthcare resources, but in sparsely populated areas, where there is one large hospital (Ruszkowski, 2010).

These inequalities in access to hospitals could have been mitigated alongside with the implementation of legislative Act on Network of Hospitals. The project of this legislation propounded a set of criteria to decide which institutions should be incorporated into Polish hospital network (hospitals that do not fulfill the criteria were either to be shut down or privatized). Among other things, these conditions included the optimal number of hospital beds with a regard to geographical distribution of medical resources. So-called regional adjustment plans were supposed to take into account "the directions of hospital infrastructure development, demographic and epidemiologic determinants and their changes in time, the structure and length of hospitalizations". Besides, these plans had to include the provision of sufficient accessibility to high-quality health services. As follows, according to the guidelines provided by the Ministry of Health a hospital must have at least 150 beds and the minimal number of beds per 10 thousand inhabitants should not be less than 40 (The projected Act on Network of Hospitals, 2007). Aforementioned project was vetoed in January 2009 due to political reasons and strong criticism from local governments (particularly controversial was the issue of closing down small hospitals). Though turned down, this project showed a great importance of geographic aspects concerning hospital network and its organization. No sooner than 15 years after transformation did the decision makers notice a need to fix the unfavorable distribution of tertiary healthcare in Poland.
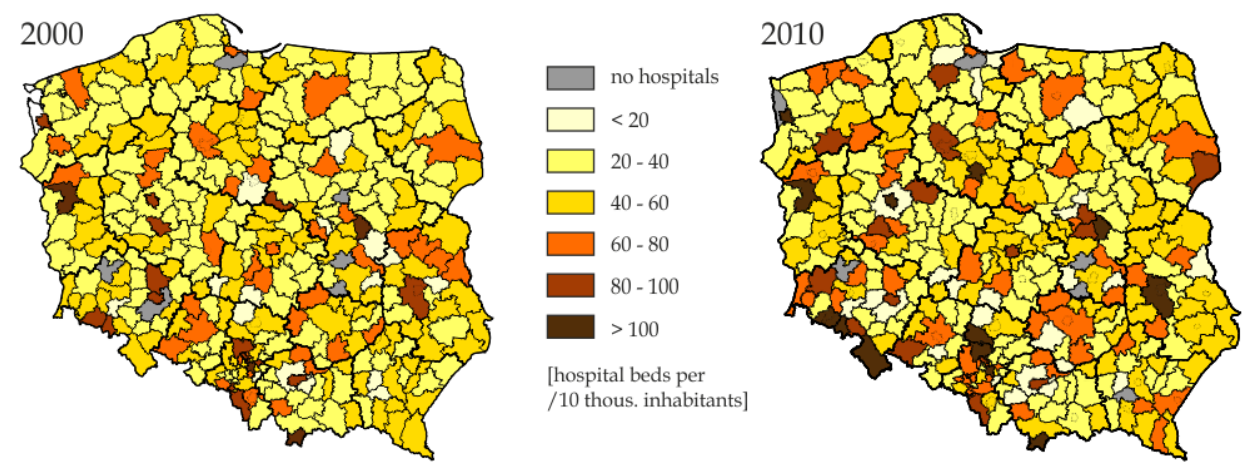

Source: Authors' own work based on Healthcare Register (www.rejestrzoz.gov.pl) and Central Statistical Office data (www.stat.gov.pl).

Fig. 6. The number of hospital beds per 10 thousands inhabitants in 2000 and 2010 (without psychiatric hospitals and facilities located in health resorts).

Currently, an increase in the number of hospital beds Poland is observed, what was not the issue shortly after socio-economic transformation in the 1990s. Figure 6 shows some mosaiclike disparities across Polish counties as measured by hospital beds per 10 thousand inhabitants. In many counties this indicator falls below the recommended 40 beds per 10 thousand inhabitants. The regions "abundant" with hospital beds include Dolnośląskie and Śląskie Provinces. Urban areas, especially these of the largest Polish cities, possess relatively high number of hospital beds, which rarely fall below 60 beds per 10 thousand patients. This 
surplus is utilized by the population of counties located in suburban zones where there are either no hospitals or some small unspecialized institutions. Counties located along the province boundaries have considerably lower number of hospital beds. Importantly, one large hospital, even though located in a small county, may have a broad catchment area. As a consequence, adjoining counties have fewer hospital beds per 10 thousand inhabitants. This attests to the inequality in spatial distribution of tertiary care in Poland. This problem particularly concerns large institutions, sizes of which often exceed local demand. Simultaneously, such hospital catchment areas become large and attract patients residing in more distant areas with no at all or only small general hospitals. The concentration of hospital resources in one place is perceived as profitable and socially approvable when these institutions offer a wide variety of specialized health services and operate as centers of scientific research and new technologies (Ferguson et al., 1997). The selective concentration of specialized hospital infrastructure in 1960s and 1970s in Poland resulted in too many hospital beds which cannot be explained neither by local demand nor accessibility of qualified personnel.

In 2000, there were 49.9 hospital beds per 10 thousand inhabitants in Poland. During next ten years this proportion increased to 55.2. However, the observed number did not always increase in accordance with in the improvements in accessibility of stationary health care and across particular medical specializations. The research conducted by the Centre of Health Care Organization and Economics by the end of 1990s showed significant inequalities in spatial distribution of long-term care beds and the necessity to increase their number significantly (Kozierkiewicz, 2008). Results of the study conducted by the National Institute of Hygiene indicated that the greatest excess of hospital beds concerns such wards as: ophthalmology, otolaryngology, pediatric surgery, obstetrics and gynecology, and especially in the west of Poland. On the other hand, shortages of hospital beds can be found on rehabilitation, hematological and oncological wards (Goryński et al., 2006). Aforementioned study was questioned by Murkowski (2007), who argues that the largest surplus of hospital beds is observed in Śląskie, Łódzkie, Lubelskie and Podlaskie Provinces, so in the central and eastern Poland. This finding is more or less congruent with the results presented in the Figure 6. On the other hand, reflections presented by Krzanowski (2007) are somewhat controversial and reveal alleged influence of healthcare system on hospital morbidity. As pointed out by this author, regional differences in hospitalization rates for certain diseases are well explained by the available number of hospital beds. Medical geographers with a sufficient experience and skills in finding spatial relations between the needs and supplies in many socio-economic domains should be included into researchers exploring this phenomenon. The application of causative and consecutive analyzes would help find solutions for Krzanowski's concern that is to tell whether and in which regions the statement "if there are spare beds, there will also be patients" can be true.

\section{Commercialization and privatization in Polish healthcare}

Commercialization and privatization in Polish healthcare are considered as key determinants of spatial and non-spatial availability to primary and hospital care in the recent years. From a spatial perspective these processes lead to an increase in the number of medical facilities, however commercialized healthcare limit affordability for both insured and uninsured citizens as some services are paid. Commercialization does not occur 
uniformly throughout the country and across medical specialties. In 2009, about 75\% general practitioner offices (max. Wielkopolskie 94\%, min. Świętokrzyskie 48\%), 82\% specialist offices (Wielkopolskie 91\%, Świętokrzyskie 70\%) and 45\% of general and specialized hospital facilities (Dolnośląskie 68\%, Świętokrzyskie 24\%) belonged to commercial entities. Changes in ownership structure are clearly reflected by inverse care law - a concept developed by Hart in 1971 (Hart, 1971). This law assumes that the availability of good medical care tends to vary inversely with the need of the population served. In other words, financial resources are not allocated in conjunction with the distribution of needs, but rather along with the distribution of resources. Location and quality of health services offered by non-public health care units become market-oriented and favor more affluent regions and social groups. The poorer patients are not as attractive customers as other inhabitants despite of higher needs reported by the former. Such situation is most characteristic for the USA - a country with a dominance of private healthcare financed by non-public insurance companies (except for the elderly and low-income groups). This organization of healthcare Whiteis (1997) calls „corporate-sponsored medicine”.

Spatial aspects concerning privatization and directions of ownership changes are presented on the example of all medical facilities, general practitioner offices and hospitals. Figure 7 depicts transformations of public health care units into non-public entities for 2004, 2007 and 2010. According to the Act of 30th September 1991 on Health Care Units non-public health care units can be founded by: churches and religious groups, employers, foundations, trade unions, professional or other associations, other national or foreign legal or natural persons or non-legal partnerships.

Changes in health care unit ownership structure evidenced by an increase of non-public facilities progresses rapidly in the whole country. In small rural communities private entities get complete or partial hold of municipal health centers followed by a contract drew with the National Health Fund. As for primary care, almost all services remain refunded by the NFZ, but in case of specialist offices some services are paid. Thus, in many areas the spatial accessibility of healthcare increases as branch offices are more likely to be opened by commercialized health care units, but this happens selectively (usually in the largest villages). Private medical offices in large cities remain market-oriented and operate under great competition. Therefore, firms locate their offices is strategic locations usually in the vicinity of potential clients e.g. in large shopping centers. A good example of this is EnelMed healthcare provider which possesses offices in the biggest shopping malls across the country: Arkadia and Blue City (Warsaw), Galeria Krakowska (Cracow), Arkady Wrocławskie (Wrocław), Manufaktura (Łódź) and Kupiec Poznański (Poznań). Some of the services offered by private healthcare firms are not refunded by the NFZ, so, in spite of improved spatial accessibility, their affordability is limited. In less populous urban areas and towns medical offices are often located in private houses what is rare in the bigger cities (except for dental offices). Unfortunately, in spite of rising market-oriented availability the possibilities to utilize health services are constrained by too high demand and annual limitations for certain services and their refund by the NFZ. As a consequence, long lines and wait times to the physicians are observed what discourages the patients and attracts them to utilize paid services (frequent in specialist offices). Free healthcare can be utilized without a need to wait after private (and paid) consultation - such practices are not uncommon. 


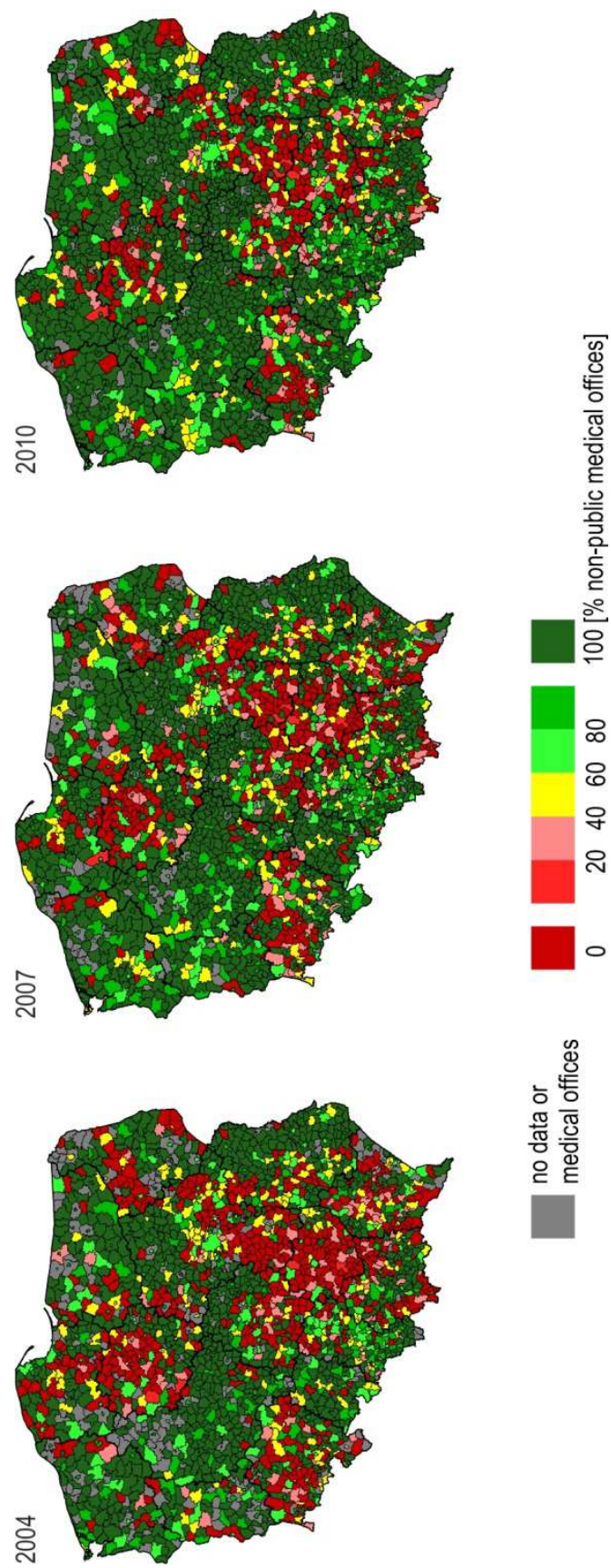

Source: Author's own work based on Central Statistical Office (www.stat.gov.pl)

Fig. 7. The share of public and commercial healthcare facilities in 2004, 2007 and 2010. 
In 2004, public healthcare units prevailed only in Świętokrzyskie and Kujawsko-Pomorskie Provinces, but in 2010 the majority of healthcare facilities in the whole country were nonpublic. Commercialization in the Polish healthcare first dominated Wielkopolskie Province, where liberal and entrepreneurial attitudes prevail among the local population. Conversely, in Świętokrzyskie and Mazowieckie Provinces left-wing political parties traditionally gain great popularity among traditionally pretentious communities. These parties strive to delay the privatization of healthcare in fear of paid services and undermined health security. Such social attitudes are clearly reflected in election results; therefore more conservative municipal authorities are not likely to foster quick changes in health care unit ownership. This selective commercialization depends on leading political fraction in local governments. Perhaps, low availability and quality of services in some areas make their residents press on local authorities for non-public care irrespective off political affiliations. This factor may be of the essence in the eastern part of the country

In primary healthcare commercialization processes occur very fast (Figure 8). In 2004 most counties had more than a half of their general practitioner offices commercialized. In 2010 about $75 \%$ of all GP practices belonged to non-public entities. Three separate areas of sizeable prevalence in the proportion of non-public facilities can be demarcated: prosperous and liberal west (Lubuskie and Wielkopolskie Provinces), most industrialized south of population traditionally emigrating to the west, Germany in particular (Śląskie and Opolskie) as well as poor eastern borderland (Lubelskie). On the other hand, Świętokrzyskie Province, the south of Mazowieckie and Łódzkie Provinces are represented by a dominance of people's and left-wing political affiliations; thus comprise a majority of areas with public healthcare offices. In other regions decisions against commercialization depend on specific local determinants.
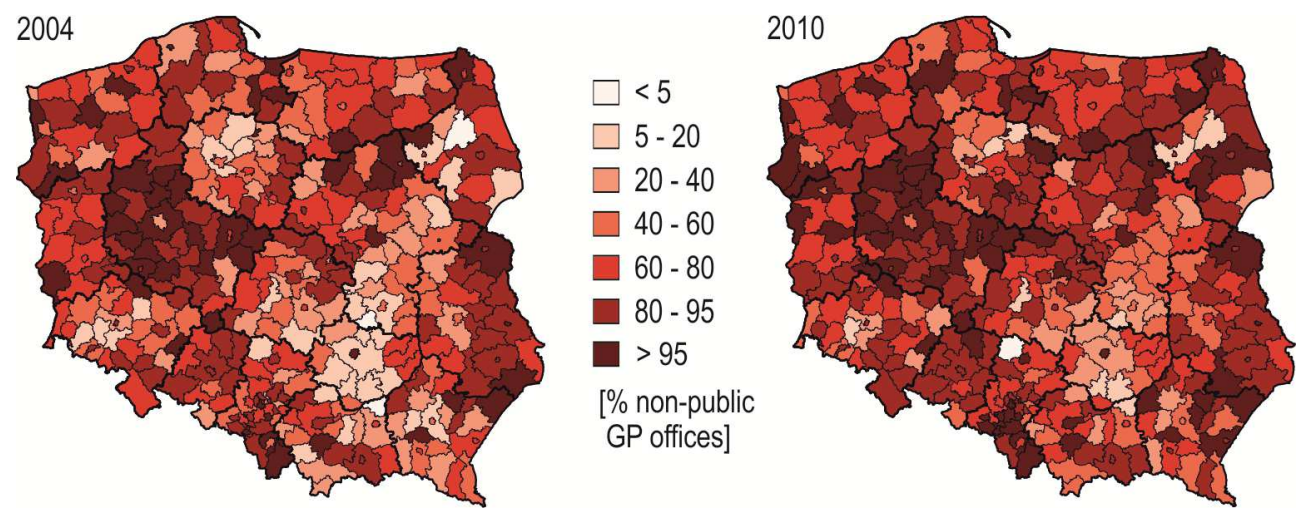

Source: Authors' own work based on Register of Health Care Units (www.rejestrzoz.gov.pl).

Fig. 8. The share of non-public general practitioner offices in 2004 and 2010

According to some scientific views the most financial problems experienced by hospitals can be easily solved by changing their ownership to join stock or commercial companies (Masiakowski, 2005; Milczarek, 2005; Rój, 2006). This does not mean that the majority of independent public health care centers (mainly hospitals) need to be converted into private 
properties because they operate with no regard to economic rationality (Jończyk, 2008). Unfortunately, considerable service overproduction and capital intensity (rising needs, new technologies in medicine and pharmacy) combined with simultaneous financial scarcities in municipal budgets led to large indebtedness. This is the main reason why commercialization processes are at issue and worry local and regional authorities as well as politicians. However, ownership changes do not result in a complete lack of control over hospitals as most shares are often hold by public bodies; thus, instead of privatization, the term commercialization better illustrates current transformation in the Polish healthcare (Misińska \& Nawara, 2008). These processes are selective and connected with restructuring and reforms in healthcare system, but particularly with vigorous attempts to clear hospitals of liability for debts. The germ of these endeavors was to be the Act of Regulations of Healthcare Legislations (so-called healthcare legislation package), which proposed mandatory choice: to convert all public hospitals into commercial companies or pay their debts by public owners (local and regional governments). In 2009, this legislation was vetoed by President Lech Kaczyński, who refused to allow for paid services and put population health security in jeopardy as some unprofitable hospitals could have been shut down in the aftermath of the new code.

Nevertheless, commercialization of healthcare facilities continues, partially fueled by financial aid of so-called Governmental B Plan. This plan promises a donation for these governments which commercialize hospital, make over all assets, property and other resources (unless a new owner already possess the resources necessary to run a hospital), and designate the entity that would take over all of the debts amassed. Most frequently, commercialized independent health care centers are converted to limited liability companies with shares held by local or regional governments. In 2004, $6.4 \%$ of all hospital beds were owned by non-public entities. In 2010, this indicator increased to $15.5 \%$, so 32.8 thousand hospital beds per 210.8 thousand in the whole Poland belonged to non-public bodies. The spatial depiction of these transformations is presented in the Figure 9.
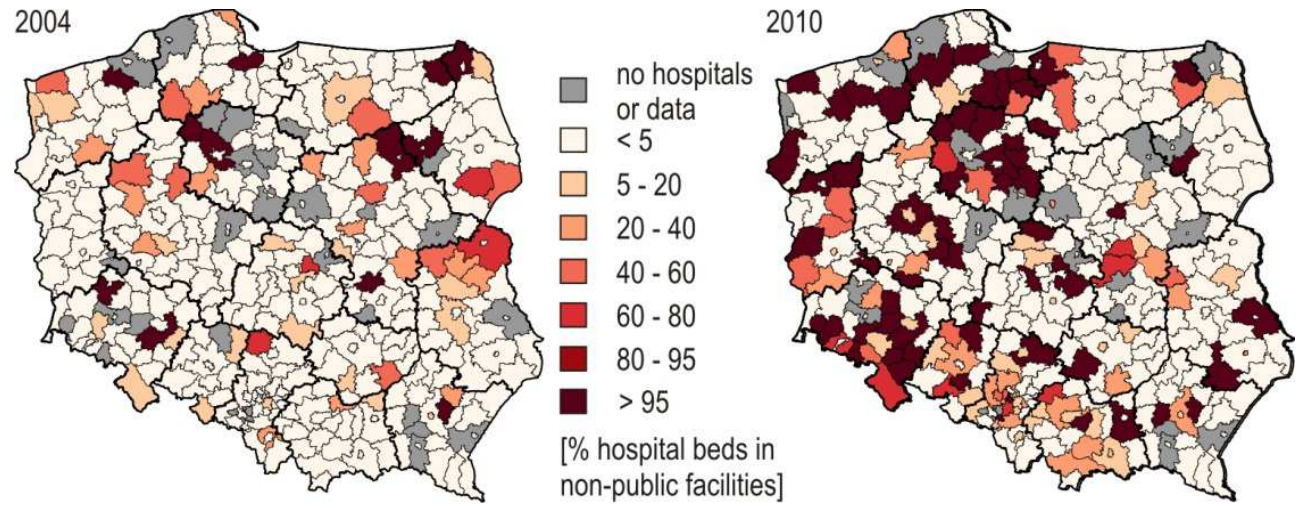

Source: Authors' own work based on Register of Health Care Units (www.rejestrzoz.gov.pl).

Fig. 9. The share of hospital beds in non-public facilities in 2004 and 2010 (without psychiatric and facilities located in health resorts, urban counties are combined with rural except the largest cities). 
The largest proportion of commercialized hospitals between 2004 and 2010 concerned Kujawsko-Pomorskie, Pomorskie and Dolnośląskie Provinces. Usually, one or largest facility was commercialized in one county, thus small disparities within counties contrast with large disparities between them. The latter, though, show a mosaic spatial configuration as a direct consequence of selective processes dependent on either undisputed and quick decisions or social protests and political unwillingness among the decision makers. Nevertheless, faster changed can be observed in western Poland what is comparable to the level of socioeconomic development.

\section{Conclusions}

In this study Polish healthcare system is characterized from spatial and organizational viewpoints. The analyses conducted show considerable regional and local disparities in access to health services across the country. While existing inequalities are evident and allow for delineation of excess/shortage areas as far as health resources are concerned, the evolution of geographical studies should aim at seeking spatial relationships between healthcare resources and population needs. Such approach has been put into practice in the USA health policy. The main purpose of Health Professional Shortage Areas (HPSA) is to identify areas of greater need for health care services and redirect limited healthcare professional resources to people in those areas. This objective is congruent with the geography of healthcare principal that is matching healthcare resources to population needs in time and space. Consequently, some apparent scientific goals also come to the fore. These include more complex cross comparisons between volume and structure of health resources and volume and structure of population needs. Such multivariate analyses ought to be able to provide answers to simple questions i.e. how many hospital beds do we need?; What hospital wards need to be expanded or downsized?; What is the optimal number of general practitioners/ practitioner offices per 10 thousand inhabitants in an area including current health, demographic and economic situation?.

Limited geographic access to primary care in Poland concerns only areas of very low population density, which are not as common as in other European counties. For that reason non-spatial limitations (including financial and legal) should forge ahead when analyzing utilization of healthcare facilities (Jones \& Moon, 1987; Powell, 1995).

This study introduces to the complexities of Polish healthcare legal and administrative foundations and spatial availability with a special regard to difficulties adversely affecting patients' access to healthcare facilities. To conclude, spatial and organizational availability of healthcare in Poland are shaped by the following phenomena and processes:

a. ineffective and extensive management of healthcare resources during the communistic times, lack of regional and local health policies, system centralization (state organization, management, planning and financing)

b. hospital locations in 1945-1989 unrelated to population needs

c. transition from budgetary to insurance healthcare model (similar to Bismarck model), contract-based financing of healthcare

d. increasing number of health care units $\rightarrow$ higher accessibility and availability (much better in metropolitan areas)

e. mosaic spatial distribution of hospital care (better availability explained by the proximity to large general hospital) 
f. increasing needs along with advancements in medicine and pharmacy as well as better availability of healthcare facilities

g. various quality of hospital services linked to the following dilemma: does contemporary hospital heal or perform contracts? A quest for balance between money saving, debt reduction and patient needs

h. the role of the general practitioner: limited in treatment, but major in administration (sick leaves, prescriptions, referrals); organizational and spatial access impeded in case of secondary healthcare

i. threats of hospital privatization and healthcare security of citizens, declining role of small hospitals, even though some may be important for peripheral areas

j. faster ownership change in the west of Poland parallel to rising socio-economic development and liberal attitudes among the locals

\section{References}

Chawla M., Berman P., Windak A., Kulis M., Provision of ambulatory health services in Poland: a case study from Krakow, Social Science \& Medicine, 58, pp. 227-235.

Curtis S., Malczewski J., 1990, Planowanie przestrzennej alokacji wydatków na ochronę zdrowia w Anglii i w Polsce - zarys badań porównawczych, [w:] Smoleń M. (Ed.), Teoria i praktyka organizacji ochrony zdrowia. Przestrzenne planowanie finansowe opieki zdrowotnej. Elementy teorii. Próba praktycznych rozwiazań, Instytut Medycyny Pracy, Łódź, pp. 63-81.

Dziubińska-Michalewicz M., 1994, Sektor prywatny w opiece zdrowotnej, wyniki badań ankietowych, Antidotum - Zarządzanie w Opiece Zdrowotnej, 12, pp. 27-34.

Ferguson B., Sheldon T.A., Posnett J., (eds.), 1997, Concentration and Choice in Healthcare, FT Healthcare, London.

Jones D. R., Moon G., 1987, Health, Disease and Society, London, Routledge and Kegan Paul. Jończyk J., 2008, Aspekty prywatyzacji szpitala, Praca i Zabezpieczenie Społeczne, 7, pp. 2-7.

Joseph, A.E., Phillips, D.R., Accessibility and Utilization - Geographical Perspectives on Health Care Delivery, Happer \& Row Publishers, New York, 1984.

Hart, J., The Inverse Care Law, The Lancet, 297, 1971, pp. 405-412.

Haynes R., Lovett A., Sunnenberg G., 2003, Potential accessibility, travel time and consumer choice: geographical variations in general medical practice registration in Eastern England, Environment and Planning A, Vol. 35, pp. 1733-1750.

Goryński P., Wojtyniak B., Kuszewski K., 2006, Ile potrzeba nam łóżek szpitalnych - zatącznik do projektu ustawy o sieci szpitali, Menedżer Zdrowia 9/2006.

Grochowski M., 1988, Rejonizacja stużby zdrowia a dostęność ustug medycznych, Rozwój Regionalny, Rozwój Lokalny, Samorząd Terytorialny 15, Uniwersytet Warszawski, Wydział Geografii i Studiów Regionalnych, Warszawa.

Guagliardo M.F., 2004, Spatial accessibility of primary care: concepts, methods and Challenges, International Journal of Health Geographies 3, 3. pp. 1-13.

Kaczmarek T., Marcinkowski J. T., Zysnarska M., Maksymiuk T., Majewicz A., 2007, Nierówności społeczne w dostępie do zdrowia, Problemy Higieny i Epidemiologii, 88, 3, pp. 259-266.

Kaser M., 1976, Health care in the Soviet Union and Western Europe, Croom Helm Limited, London. 
Kearns R. Moon G., 2002, From medical to health geography: novelty, place and theory after a decade of change, Progress of Human Geography, 26, 5, pp. 605-625.

Kozierkiewicz A., 2008, Koło ratunkowe dla szpitali. Od doświadczeń do modelu restrukturyzacji, Termedia, Warszawa.

Krzanowski M., 2007, Są tóżka, będą i chorzy..., Rynek Zdrowia 4/2007, pp. 48-49.

Malczewski J., 1989, Optymalizacja obszarów obstugi placówek podstawowej ochrony zdrowia, Przegląd Geograficzny, T. LXI, z. 1-2, pp. 23-31.

Masiakowski A., 2005, Prywatyzacja w ochronie zdrowia, Zdrowie Publiczne 115, 2, pp. 252253.

Mayer, J. D., 1982, Relation between two traditions of medical geography: health system planning and geographical epidemiology, Progress in Human Geography, 6, pp. 216-230.

Mazurkiewicz L., 1994, Czy geografia człowieka powinna zajmować się problematyka zdrowia, Przegląd Geograficzny, t. LXVI, z. 1-2, pp. 191-195.

Michalski T., 1999, Nowe nurty $w$ światowej $i$ polskiej geografii medycznej, Kwartalnik Geograficzny, 4, 12, pp. 85-89.

Milczarek M., 2006, Warunki ekonomiczno-finansowe dziatalności i rozwoju szpitali. Perspektywy i niezbędne działania, Polityka Zdrowotna, t. 3, Instytut Polityki Ochrony Zdrowia przy Uniwersytecie Medycznym, pp. 7-9.

Millard F., 1995, Changes in the health care system in post-communist Poland, Health \& Place 1, 3, pp. 179-188.

Misińska B., Nawara P., 2008, Publiczna i prywatna własność w systemie ochrony zdrowia w kontekście form organizacyjno-prawnych prowadzenia działalności medycznej, [w:] Ryć K., Skrzypczak Z. (Ed.), Ochrona zdrowia i gospodarka - mechanizmy rynkowe a regulacje publiczne, Wydawnictwo Naukowe Wydziału Zarządzania Uniwersytetu Warszawskiego, Warszawa, pp. 335-344.

Ministerstwo Zdrowia, 2006, Wskaźniki do tworzenia projektu tworzenia sieci szpitali $z$ elementami analizy sytuacji demograficznej i stanu zdrowia ludności, Materiał przygotowany dla Ministra Zdrowia przez Państwowy Zakład Higieny na podstawie danych Centrum Informacyjnych Ochrony Zdrowia i Państwowego Zakładu Higieny dotyczących infrastruktury szpitali i ich działalności, Warszawa.

Moon G., Gould M. and Jones K., 1998, Seven up - refreshing medical geography: an introduction to selected papers from the Seventh International Symposium in Medical Geography, Portsmouth, UK. Social Science \& Medicine 46, pp. 627-30.

Murkowski M., 2007, W sieci niekompetencji, Menedżer Zdrowia, 4/2007, pp. 21-24.

Parr, H., 2003, Medical geography: Care and caring, Progress in Human Geography, 27, 2, pp. 212-221.

The projected act of Network of Hospitals, (Projekt ustawy o krajowej sieci szpitali), Ministerstwo Zdrowia, available on the Ministry of Health website website:http://www.mz.gov.pl/wwwfiles/ma_struktura/docs/u_siec_szpitali_ke rm_17052007.pdf, Access: 12/17/2010.

Penchansky R., Thomas J.W., 1981, The Concept of Access, Medical Care 19, 2, pp. 127-140.

Powell M., 1995, On the outside looking in: medical geography, medical geographers, and access to health care, Health\&Place, Vol. 1, No. 1., pp. 41-50.

Register of Healthcare Units official website - www.rejestrzoz.gov.pl.

Rosenberg M. W., Medical or health geography?: populations, peoples and places, International Journal of Population Geography, 4, 1998, pp. 211-226 
Rój J., 2006, Forma organizacyjno-prawna a gospodarka finansowa szpitala, [w:] Węgrzyn M., Wasilewski D. (Ed.), Komercjalizacja i prywatyzacja ZOZ - kluczowe warunki osiagnięcia sukcesu, Prace naukowe AE Wrocław, pp. 53-58.

Ruszkowski J, 2008, Polski system zdrowotny - socjalizm w rynkowym otoczeniu, [w:] Ryć K., Skrzypczak Z. (Ed.), Ochrona zdrowia i gospodarka - mechanizmy rynkowe a regulacje publiczne, Wydawnictwo Naukowe Wydziału Zarządzania Uniwersytetu Warszawskiego, Warszawa, pp. 29-42.

Ruszkowski J., 2010, Zwiększenie bezpieczeństwa zdrowotnego, ekspertyza finansowana ze środków projektu nr POPT.03.04.00-00-019/07 w ramach Programu Operacyjnego Pomoc Techniczna 2007-2013 wykonana na zlecenie Ministerstwa Rozwoju Regionalnego.

Siwińska V., Brożyniak J., Iłżecka I., Jarosz M. J., Orzeł Z., 2008, Modele systemów opieki $z$ drowotnej w Polsce $i$ wybranych państwach europejskich, Zdrowie Publiczne, 118, 3, pp. 358-367.

Świadczenia opieki zdrowotnej finansowane ze środków publicznych, Vademecum issued by National Health Fund, National Health Fund, Poland, 2011.

Unal E., Chen S.E., Waldorf B.S., 2007, Spatial accessibility of health care in Indiana, Purdue University Working Papers, West Lafayette, paper nr 07-07.

The Act of $28^{\text {th }}$ October 1948 on Collective Health Care Centers and Planned Economy in Healthcare as published in Dziennik Ustaw No. 55, Item 434 (Ustawa z dnia 28 października 1948 r. o zakładach społecznych stużby zdrowia i planowej gospodarce w stużbie zdrowia, Dz.U. 1948 Nr 55, Poz. 434.)

The Act of 30th September 1991 on Health Care Units as published in Dziennik Ustaw No. 220, Item 1600 (Ustawa z dnia 30 września 1991 o zakladach opieki zdrowotnej; Dz.U. 1991, Nr 220, Poz. 1600.).

The Act of 6 th November 2008 on Code Indroducing Healthcare Legislations, Presidential veto legislation not passed by the parliament (Ustawa z dnia 6 listopada 2008 r. Przepisy wprowadzajace ustawy z zakresu ochrony zdrowia),

(http://orka.sejm.gov.pl/proc6.nsf/ustawy/294_u.htm), Access: 03/14/2011.

The Act of Regulations of Healthcare Legislations, vetoed by President Lech Kaczyński in 2009.

The Constitution Of The Republic Of Poland of 2nd April, 1997 as published in Dziennik Ustaw No. 78, Item 483.

The Polish Chamber of Physicians and Dentists official website - www.nil.org.pl

The Central Statistical Office Local Databank website - www.stat.gov.pl

Wang, F. and Luo, W., 2005, Assessing spatial and nonspatial factors for healthcare access: towards an integrated approach to defining health professional shortage areas, Health \& Place, 11, pp. 131-146.

Whiteis D. G., 1997, Unhealthy cities: corporate medicine, community economic underdevelopment and public health, International Journal of Health Services, 27, pp. 227-242. 


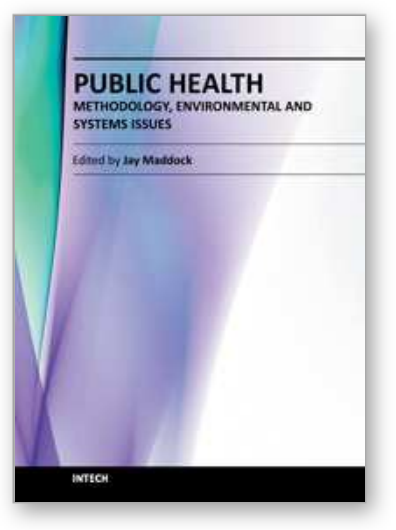

\author{
Public Health - Methodology, Environmental and Systems Issues \\ Edited by Prof. Jay Maddock
}

ISBN 978-953-51-0641-8

Hard cover, 432 pages

Publisher InTech

Published online 30, May, 2012

Published in print edition May, 2012

Public health can be thought of as a series of complex systems. Many things that individual living in high income countries take for granted like the control of infectious disease, clean, potable water, low infant mortality rates require a high functioning systems comprised of numerous actors, locations and interactions to work. Many people only notice public health when that system fails. This book explores several systems in public health including aspects of the food system, health care system and emerging issues including waste minimization in nanosilver. Several chapters address global health concerns including non-communicable disease prevention, poverty and health-longevity medicine. The book also presents several novel methodologies for better modeling and assessment of essential public health issues.

\title{
How to reference
}

In order to correctly reference this scholarly work, feel free to copy and paste the following:

Paweł Kretowicz and Tomasz Chaberko (2012). Primary and Hospital Healthcare in Poland - Organization, Availability and Space, Public Health - Methodology, Environmental and Systems Issues, Prof. Jay Maddock (Ed.), ISBN: 978-953-51-0641-8, InTech, Available from: http://www.intechopen.com/books/public-healthmethodology-environmental-and-systems-issues/primary-and-hospital-healthcare-in-poland-organizationavailability-and-space

\section{INTECH}

open science | open minds

\author{
InTech Europe \\ University Campus STeP Ri \\ Slavka Krautzeka 83/A \\ 51000 Rijeka, Croatia \\ Phone: +385 (51) 770447 \\ Fax: +385 (51) 686166 \\ www.intechopen.com
}

\author{
InTech China \\ Unit 405, Office Block, Hotel Equatorial Shanghai \\ No.65, Yan An Road (West), Shanghai, 200040, China \\ 中国上海市延安西路65号上海国际贵都大饭店办公楼405单元 \\ Phone: +86-21-62489820 \\ Fax: +86-21-62489821
}


(C) 2012 The Author(s). Licensee IntechOpen. This is an open access article distributed under the terms of the Creative Commons Attribution 3.0 License, which permits unrestricted use, distribution, and reproduction in any medium, provided the original work is properly cited. 